\title{
Fund Mobilization by Insurance Companies and Fixed Capital Formation: Evidence from the Nigerian Economy
}

\author{
Lezaasi Lenee Torbira ${ }^{1} \&$ Onyemachi Maxwell Ogbulu ${ }^{2}$ \\ ${ }^{1}$ Department of Finance and Banking, Faculty of Management Sciences, University of Port Harcourt, Port Harcourt, \\ Nigeria \\ ${ }^{2}$ Department of Banking and Finance, Abia State University, Uturu, Nigeria \\ Correspondence: Onyemachi Maxwell Ogbulu, Department of Banking and Finance, Abia State University, Uturu, \\ Nigeria. E-mail: hrhogbulu@yahoo.com
}
Received: November 22, 2013
Accepted: February 4, 2014
Online Published: March 30, 2014
doi:10.5430/ijfr.v5n2p69
URL: http://dx.doi.org/10.5430/ijfr.v5n2p69

\begin{abstract}
This paper is an empirical investigation into the relationship between fund mobilization by insurance companies and gross fixed capital formation (GFCF) in Nigeria and specifically how the latter responds to stimuli emanating from the insurance companies. A five variable-predictor multivariate regression model was estimated and analyzed. The short run results reveal that four explanatory variables namely: premium from fire, accidents, motor vehicles and employee liabilities insurance policies positively and insignificantly correlate with Gross Fixed Capital Formation while the relationship between premium from marine insurance policies and GFCF is both negative and insignificant. In the long run, the fund mobilization variables by insurance companies positively and significantly impact on the growth of gross fixed capital formation. In addition, the Granger causality test provides no evidence of causality among the variables. The paper therefore recommends the formulation and implementation of policy measures that will increase insurance penetration, improve insurance fund mobilization and enlarge the insurance market in Nigeria.
\end{abstract}

Keywords: fund mobilization, gross fixed capital formation, insurance premium, co-integration, variance decomposition and impulse-response function

\section{Introduction}

An important function of financial intermediaries such as insurance companies in an economy is the mobilization of funds across all income levels and geographical areas, adequately, timely and at the minimal cost. That is, to mobilize savings from savings-surplus economic units and channel same to savings-deficit economic units like the business sector. Thus, insurance companies sell their liabilities to raise funds that are used to purchase liabilities of other companies (Bodie, Kane and Marcus, 2005). Insurance companies raise funds by selling policies and taking in savings deposits and adequately investing these deposits in various forms of insurance investment as provided for in section 25 (2) of The Insurance Act of Nigeria 2003. The convenience, risk reduction, transfer and indemnity the insurance companies offer their customers/policy holders allow insurance companies to profit from the difference or spread between the aggregate of the mobilized premium/savings and the return on the various investments on one side, and the cost of indemnity on the other side.

Insurance companies are distinguished from other businesses in that both their assets and their liabilities are overwhelmingly financial in nature but the investments can specifically and collectively translate into growth in capital formation in the economy. Given that the extent of insurance investment seem to be a function of the quantum of fund mobilized, it logically follows that, fund mobilization by insurance companies may influence capital formation in the economy.

Theoretically speaking, fund mobilization activities of insurance companies is expected to impact positively on the economy if the various forms of insurance policies accumulate savings and premium to form a large pool of investible funds that will boost capital formation and stimulate economic growth. The economy will feel the effect of the fund mobilization more positively when the rate of change in the premium mobilized from the various insurances are on the increase. This will be an indicator of growth in insurance penetration in the economy. For the economy to 
grow optimally, capital formation must respond appropriately to innovations in fund mobilization activities by insurance companies.

The effectiveness and efficiency of the insurance fund mobilization process as well as its channels, scope and capacity differ reasonably from that of other financial institutions in the economy, and a rigorous analysis of the channel and economic implications of insurance fund mobilization in the capital formation process is not well documented in Nigeria. As at date, very few studies have been carried out within the Nigerian context to explore the nature and extent of the relationship between insurance activities and fixed capital formation in the country. In addition and more perplexing, is the absence of any consensus among the extant scanty literature as to the exact nature of the relationship between funds mobilized by insurance companies and capital formation.

Given this scenario, this study attempts to investigate critically and specifically, the relationship between insurance fund mobilization variables and growth in gross fixed capital formation in Nigeria. Furthermore, the paper examines the response of gross fixed capital formation to innovations or shocks emanating from insurance fund mobilization variables.

The findings of this study will be of immense importance to the managers of Nigerian economy, investors, researchers and even financial analysts who may have deep interest in understanding the fund mobilization behaviour of insurance companies and its implications for gross fixed capital formation in Nigeria. The remaining parts of this paper are organized into four sections. Section two presents the prior literature review and section three discusses the methodology. Section four contains the empirical findings and results while section five gives the concluding remarks.

\section{Literature Review}

Reed, Cotter, Gill and Smith (1980) advanced two approaches aimed at explaining the behaviour of financial institutions in respect of fund mobilization. They started with the Pool of Funds approach, which anchor on the premise that all insurance funds (premium and savings) should be pooled and allocated to various insurance investments (real estate and mortgages, loans, securities, cash etc) according to their return implication without much consideration to the source of the funds. The second theory called the Asset Allocation and Conversion of Funds approach posits that mobilized funds should be invested in different assets thereby forming various portfolios. This approach distinguishes between different sources of funds and requires that the source of fund be put into consideration in taking allocation decisions. The theory considers the source of funds and encourages insurance companies to comply with the matching principles of investments.

Given this theoretical foundation to the concept of fund mobilization, some empirical works have been conducted at various times and in different climes to test the validity of these theories. For example, Kugler and Ofoghi (2005) used the components of insurance premiums (disaggregated analysis) and real GDP to investigate the long run relationship between development in insurance market size and economic growth in the United Kingdom. By disaggregating total insurance premium, they attempt to solve the aggregation problem with a view to examining whether the results of Ward's and Zurbruegg's (2000) study that reported no long run relationship will be sustained. The authors made use of Johansen's trace and maximum co-integration tests as well as Granger causality equations. The co-integration test results showed that, in most cases, there exists a long- run relationship between insurance market size and economic growth. The causality test result provided information about the possible pattern or direction of the relationship by revealing that causality runs in both directions. That is, both life, property and liability insurance premiums Granger cause growth in real GDP and vice versa.

In another related work, Park, Borde and Choi (2002) studied the linkage between insurance penetration and Gross National Product (GNP). They employed some socio-economic factors adopted from Hofstede (1983) such as uncertainty, avoidance, individualism - collectivism, power distance, masculine-feminine, SPI index and index of economic freedom. They applied the ordinary least squares estimation technique on a cross-sectional data for thirty eight (38) countries including twelve European Union (EU) countries in 1997. On the whole, the evidence from this study suggests that there is a significant relationship between GNP, masculinity, socio-political instability, economic freedom and insurance penetration. All other factors were found to be insignificant and were subsequently dropped after checking for heteroscedasticity. Furthermore, deregulation was found to be a way to facilitate growth in the insurance industry just as socio-political instability was found to be more of a proxy for poverty than an indicator for the need to insure. This assertion supports the expectations of Kong and Singh (2005).

Webb, Grace and Skipper (2002) investigated the effect of banking and insurance on the growth of capital and output. Employing a Solow-Swan model with productivity parameters estimated across fifty-five (55) countries including 
seventeen EU countries for the period 1980-1996, the authors used the ordinary least square (OLS) estimation method on the panel data. Their findings indicate that the components of banking and life insurance penetration are found to be robustly predictive of increased productivity. When split into the three areas of banking, life insurance sector and property and liability insurance sector, it is only the banking and life insurance sector that remain significantly related to Gross Domestic Product (GDP). Property and liability insurance penetration was found not significantly correlated with GDP. The result of the study suggests that higher levels of banking and insurance penetration jointly produce a greater effect on growth than would be indicated their individual contributions. Their findings indicate that financial intermediation inclusive of insurance penetration significantly correlate with Gross Domestic Product GDP. This suggests that insurance intermediation is a determinant of economic growth.

Haiss and Sumegi (2008) studied the relationship between insurance and economic growth. They identified the channels of influence to be risk transfer, savings substitution, investments and assets, institutional, credit derivatives and contagion. Through the analysis of the fundamental functions of insurance and their implication for the economy, they adopted an endogenous growth model with a modified Cobb-Douglas production function. Use was also made of the OLS and granger causality techniques on an unbalanced cross- country panel data for twenty nine (29) European countries over the period 1992 to 2004.

Real GDP was regressed against annual gross premium income and also on premium income split into life and non-life premium income. Other explanatory variables employed include real physical capital stock, human capital stock, inflation rate and interest rate. The study reported positive and significant relationship between real GDP and physical capital. Human capital seems to be negatively related to GDP growth while Interest rate and inflation rate do not significantly correlate with real GDP. Total insurance premium income and non-life insurance premium income negatively and insignificantly affects the growth of the economy, while life insurance premium income has a positive but insignificant impact on the output level of goods and services in the economies. This result suggests weak evidence for a growth- supporting role of insurance.

Avran, Nguyen and Skully (2010), provided a behavioural explanation for the impact of insurance density and insurance penetration on GDP per capital in ninety-three (93) countries from 1980 to 2006. The study adopted the (OLS) and generalized method of moments (GMM) estimation approaches in analyzing the global insurance sector. Consequently, a cross- country panel data for the various countries was used for the analysis. The results from the study confirm that insurance density positively and significantly causes growth in the economy while insurance penetration does not have significant effect on economic growth. The relationship was demand-leading for insurance density but not for insurance penetration. This study concludes that insurance density in an economy helps boost risk management, intermediation and investment and implicitly enhances growth. Although the results from this study are insightful, the study was based on the assumption that variations which affect insurance density will affect growth.

Majekwu, Agwuegbo and Olowokudejo (2011) for instance, studied the impact of insurance contributions on economic growth in Nigeria over a twenty-seven year period, between 1981 and 2008. The study employed the dynamic factor model on a multivariate time series which analyze a functional relationship between the volume of insurance contribution and economic growth in terms of underlying but unobserved random factors. The results of the study summarily reveal that real gross domestic product is positively correlated to insurance contributions. This implies that if insurance contributions increase, economic growth will also increase. The finding supports that of Boon (2005) who also found in his study that total insurance funds affect both capital formation and GDP growth in the short and long run. The plausibility of the aforementioned findings may be ascribed to the fact that insurance activities rely a lot on investment. They recommended that government policy should be directed at growing the insurance industry in the country and through such means enhance investment as well as production in order to boost the country's economic growth.

Catalan, Impavido and Musalem (2000) studied the link between insurance and economic growth by focusing on the intermediation function of the insurance sector and its transmission mechanism (contractual savings, portfolio setup and the capital market) to the growth of the economy. They examined specifically, the impact of insurance assets (contractual savings, pension fund, life and non life, market capitalization and value of stocks traded in the capital market on Gross Domestic Product (GDP) for fourteen (14) OECD countries and five (5) developing economies over the period 1975-1997. Use was made of the OLS and Granger causality models for estimation. Their findings show that contractual savings seem to correlate with market capitalization (MC) and value of stocks traded in most countries. Market capitalization correlates with pension funds while the results of the relationship between pension funds and value of stock traded is mixed. The test result shows that there is a relationship between life insurance assets and market capitalization for nine OECD countries but the results for the developing economies were mixed. 
The study reported a weak relationship between life insurance assets and value of stocks traded in OECD countries while the relationship in most of the developing economies is strong.

It was further reported that the impact of the non-life insurance assets were almost equal to the impact of the life insurance assets on market capitalization but their impact on value of stocks traded was less. There also exists a relationship between contractual savings and market capitalization and between contractual savings and value of stocks traded for OECD countries, especially for economies with small and tight markets but enabling regulatory environment. The results of the relationship between contractual savings and market capitalization as well as value of traded securities for the 5 developing economies were mixed possibly due to their different regulatory restrictions. The findings suggest that appropriate sequencing of the development of financial institutions be carried out in favour of contractual savings institutions.

In his study, Boon (2005) examined the growth-supportive functions of banks, stock markets and the insurance sector in Singapore for the years 1991 to 2002. He regressed real GDP and real gross fixed capital formation against total insurance funds, stock market capitalization as percentage of nominal GDP and bank loans to nominal GDP using the vector error correction model on a time series data. The results showed short and long run causality running from bank loans to GDP and a bi-directional causality between real gross fixed capital formation and bank loans. GDP growth seems to enhance stock market capitalization in the short run and the stock market capitalization significantly granger causes capital formation in the long run. Total insurance funds significantly affect GDP growth in the long run while total insurance funds influence capital formation in both the short run and long run respectively.

\section{Methodology and Data}

The methodology of this work employs the impact model to capture relative effects of the correlates. This study is designed to synchronize with the hypothetico-deductive research method which also includes correlation and econometric investigation procedures involving specification of the models used to measure the subject of interest, obtaining estimates of the parameters, checking for model adequacy, testing of the hypotheses and examining the utility of the estimates/model for policy purposes. (Gujarati and Porter, 2009)

The study applies time series regression analysis. The population of interest includes all the insurance companies operating in Nigeria as provided for in Section 2 (2) of the Insurance Act, 2003. The sample chosen for this study includes the insurance companies listed on the Nigerian Stock Exchange (NSE) and the Pension Fund Administrators (PFAs) operating in Nigeria. The study involves the collection of secondary data for estimation from various issues of The CBN Statistical Bulletin, The National Insurance Commission Annual Reports, The National Pension Commission Annual Reports and the Nigerian Stock Exchange Fact book, (various issues).

Annual data on the dependent and independent variables from 1980-2011 are all converted from their absolute values to rates of change and expressed on annual basis in order to capture their growth and performance patterns. The E-Views 3.1 and 7.0 software packages are used to aid analysis of data collected.

Operationally, Gross Fixed Capital Formation (GFCF) measures the value of acquisitions of new or existing fixed assets by the business sector, governments and households which represents value added in the economy that are invested rather than consumed, while insurance premium is the payment that the insurer receives from the insured. It is a fund mobilization mechanism or savings device.

We construct the following models capturing the component effect of non life insurance premium on GFCF as follows:

\subsection{Functional Form}

$$
\mathrm{GFCF}=\mathrm{f}(\mathrm{PE}, \mathrm{PA}, \mathrm{PMV}, \mathrm{PEL}, \mathrm{PMA})
$$

Where $\quad \mathrm{PE}=$ Premium from Fire policies

PA $=$ Premium from Accident policies

$\mathrm{PMV}=$ Premium from Motor Vehicle policies

$\mathrm{PEL}=$ Premium from Employers Liabilities policies

PMA = Premium from Marine policies

Expressing (1) in explicit form gives:

$$
\begin{gathered}
\mathrm{GFCF}=\mathrm{b}_{0}+\mathrm{b}_{1} \mathrm{PE}+\mathrm{b}_{2} \mathrm{PA}+\mathrm{b}_{3} \mathrm{PMV}+\mathrm{b}_{4} \mathrm{PEL}+\mathrm{b}_{5} \mathrm{PMA}+\mathrm{u}_{\mathrm{t}} \\
\mathrm{b}_{1}, \mathrm{~b}_{2}, \mathrm{~b}_{3}, \mathrm{~b}_{4}, \mathrm{~b}_{5}>0
\end{gathered}
$$


Recasting equation (2) in the log-linear form, we have:

$$
\begin{gathered}
\mathrm{L}_{\mathrm{n}} \mathrm{GFCF}=\mathrm{L}_{\mathrm{n}} \Psi_{0}+\Psi_{1} \mathrm{~L}_{\mathrm{n}} \mathrm{PE}+\Psi_{2} \mathrm{~L}_{\mathrm{n}} \mathrm{PA}+\Psi_{3} \mathrm{~L}_{\mathrm{n}} \mathrm{PMV}+\Psi_{4} \mathrm{~L}_{\mathrm{n}} \mathrm{PEL}+\Psi_{5} \mathrm{~L}_{\mathrm{n}} \mathrm{PMA}+\mathrm{V}_{\mathrm{t}} \\
\Psi_{1}, \Psi_{2}, \Psi_{3}, \Psi_{4}, \Psi_{5}>0
\end{gathered}
$$

Where $b_{0}$ is intercept, $b_{\text {is }}$ are parameters and $\Psi_{\text {is }}$ are elasticities. Other variables are as previously defined.

The causal relationship between GFCF and the insurance premium factors (IPF) can be expressed as

$$
\mathrm{GFCF}=\sum \mathrm{GFCF}_{\mathrm{t}-\mathrm{j}}+\sum \mathrm{b} \mathrm{IPF}_{\mathrm{t}-\mathrm{j}}+\mathrm{u}_{\mathrm{t}}
$$

The analytical framework of the research consists of ten basic steps carried out on the models specified below. They are the Descriptive statistical analysis, Correlation matrix, Unit root test, Diagnostic tests, Ordinary least squares regression method, Vector error correction mechanism (VECM), Co-integration test, Granger causality test, Impulse response analysis(IRF) and Variance decomposition analysis(VDA).

\section{Estimation Results and Analysis}

Empirical analysis commences with an examination of the descriptive properties of the data in our time series. The statistical behaviour of the data on the variables in the models is reported in Table 1.

Table 1. Descriptive statistics results

\begin{tabular}{llllllllll}
\hline Variable & Mean & Median & Max & Minimum & STD Dev. & Skewness & Kurtosis & JB & PV \\
\hline GFCF & 24,2715 & 22.2253 & 92.258 & -31.387 & 28.174 & 0.287 & 2.7518 & 0.5226 & 0.770 \\
\hline PF & 30.754 & 17.684 & 259.547 & -35.240 & 53.285 & 2.765 & 11.993 & 148.6 & 0.000 \\
\hline PA & 26.542 & 24.323 & 142.415 & -100.000 & 44.506 & 0.3577 & 5.454 & 8.71 & 0.013 \\
\hline PMV & 24.034 & 16.813 & 112.399 & -21.457 & 32.057 & 1.392 & 4.553 & 13.556 & 0.001 \\
\hline PEL & 32.0543 & 9.6031 & 295.645 & -52.506 & 79.393 & 2.252 & 7.348 & 52.26 & 0.000 \\
\hline PMA & 101.298 & 19.59967 & 1789.08 & -93.301 & 338.382 & 4.270 & 21.070 & 532.62 & 0.000 \\
\hline
\end{tabular}

Source: Author's computation

The mean value of the changes in premium from marine insurance policies is the highest in the model. The changes in premium from accident insurance policies maintained the largest central value of $24.32 \%$, while growth rate of premium from marine insurance policies maintained the widest spread of data from 1,789.08 to -93.301. Hence, it is the variable with the highest range. PMA, PEL and PF are the three most dynamic variables in the model with standard deviation values of 338.4; 79.4 and 53.3 respectively.

Judging from the largeness of the mean values relative to the median values in all the variables, we observe that all the variables in the model are positively skewed toward normality. With the exception of the kurtosis of GFCF which is less than 3, the kurtosis of all other variables in the model is greater than 3 , suggesting that, GFCF is platytokurtic while the rest are leptokurtic in nature.

The probability value of Jarque-Bera (JB) statistic for all the explanatory variables are significant at $95 \%$ confidence level while that of GFCF is not. This implies that all the explanatory variables in model four are normally distributed while GFCF may not be normally distributed.

\begin{tabular}{|c|c|c|}
\hline Variable & $\begin{array}{l}\text { Test Statistic at } 1^{\text {st }} \\
\text { difference }\end{array}$ & Order of Integration \\
\hline GFCF & -8.931846 & $1(1)$ \\
\hline $\mathrm{PF}$ & -8.002137 & $1(1)$ \\
\hline $\mathrm{PA}$ & -8.560393 & $1(1)$ \\
\hline PMV & -6.723083 & $1(1)$ \\
\hline PEL & -6.115640 & $1(1)$ \\
\hline PMA & -6.297821 & $1(1)$ \\
\hline
\end{tabular}

The Augmented Dickey Fuller ADF test summary results are presented in Table 2.

Table 2. ADF unit root test results

Critical Values: $1 \%=-3.6752 ; 5 \%=-2.9665 ; 10 \%=-2.6220$

From the unit root test result displayed in Table 2, all the variables in the model are stationary at first difference. As such, the series are all integrated series of order 1 (1). We can therefore advance in our analysis to test for the long-run co-integrating relationship between the variables. 
Table 3. Summary of diagnostic test result

\begin{tabular}{lllll}
\hline Test statistics & L.M. Version & Prob. Value & F-Version & Prob. Value \\
\hline J.B. Normality Test & 4.015437 & 0.128385 & - & - \\
\hline $1^{\text {st }}$ order serial correlation & 3.785503 & 0.285577 & 1.803525 & 0.1735 \\
\hline White Heteroskedasticity & 18.41609 & 0.560019 & 0.745651 & 0.7265 \\
\hline Ramsey Reset & 14.2344 & 0.0271 & 1.9608 & 0.1176 \\
\hline
\end{tabular}

Source: Author's computation

(a) Normality Test: The probability value of the Jarque-Bera statistics of 0.128385 is greater than 0.05 , hence, the residuals of the variables specified in model four may not be normally distributed. We reject the alternative hypothesis of normality because the J.B value is not significant at $5 \%$ significant level.

(b) Serial Correlation Test: The result of the Breusch-Godfrey first order serial correlation test in Table 3 report that the probability value of 0.2856 and 0.1736 of L.M value and F- statistics are not significant at $95 \%$ confidence level. We therefore reject the alternative hypothesis that the error terms are independent, suggesting that the successive error terms are serially correlated. This is not consistent with apriori expectation.

(c) White-Heteroscedasticity Test: Given the predetermined probability level of 0.05 , we found that the probability of the L.M. Chq statistics of 0.560019 is greater than 0.05 , pointing to the fact that the successive error terms are heteroscedastic in nature which is not in line with the basic OLS assumptions.

\section{(d) Functional Form of the Model}

$\mathbf{H}_{\mathbf{0}}$ : The model is not well specified

$\mathbf{H}_{\mathbf{1}}$ : The model is well specified.

Given that the L.M. CHQ statistics of 0.0271 is significant at $5 \%$ level of significance, we reject the null hypothesis that the model is not well specified and posit that the model is well specified and well fitted such that it measures the exact relationship between the growth in gross fixed capital formation and the various components of premium collected on various non-life insurance policies in Nigeria.

Table 4. OLS level series test results

\begin{tabular}{lllll}
\hline Dependent Variable: GFCF & & & \\
\hline Variable & Coefficient & Std. Error & t-Statistic & Prob. \\
\hline PF & 0.148292 & 0.116288 & 1.275216 & 0.2131 \\
\hline PA & 0.112 & 0.129656 & 0.86382 & 0.3953 \\
\hline PMV & 0.301925 & 0.181113 & 1.667056 & 0.1071 \\
\hline PEL & 0.059861 & 0.074979 & 0.79837 & 0.4316 \\
\hline PMA & -0.001345 & 0.015983 & -0.08414 & 0.9336 \\
\hline R-squared & -0.035 & \multicolumn{3}{c}{ Adjusted R-squared } \\
\hline Durbin-Watson stat & 1.859287 & & -0.188333 \\
\hline
\end{tabular}

Source: Author's computation.

The OLS level series regression result in Table 4 presents a positive and insignificant association between PF and GFCF; PA and GFCF; PMV and GFCF; as well as between PEL and GFCF. These relationships are insignificant and weak, though positive in nature. Changes in premium from marine policies (PMA) displayed a negative and insignificant relationship with gross fixed capital formation (GFCF) such that, a $1 \%$ increase in PMA would lead to about $0.001 \%$ decrease in GFCF. In addition, the result reveals that disaggregated premium collected on various insurance policies does not significantly influence growth in gross fixed capital formation. Changes in the component premiums collected from different non-life insurance policies do not translate into growth in the output level of GFCF in Nigeria. That is, it does not boost savings and investment significantly. 
Table 5. Johansen co-integration test result

\begin{tabular}{llllc}
\hline Eigenvalue & Likelihood Ratio & Critical Value & Critical Value & Hypothesized No. of CE(s) \\
\hline 0.867696 & 156.0778 & 94.15 & 103.18 & None $* *$ \\
\hline 0.721273 & 95.39833 & 68.52 & 76.07 & At most $1 * *$ \\
\hline 0.586136 & 57.07269 & 47.21 & 54.46 & At most $2 * *$ \\
\hline 0.467789 & 30.60614 & 29.68 & 35.65 & At most $3 *$ \\
\hline 0.296784 & 11.68471 & 15.41 & 20.04 & At most 4 \\
\hline 0.036709 & 1.121993 & 3.76 & 6.65 & At most 5 \\
\hline
\end{tabular}

Source: Author's computation

Based on the likelihood ratios and the critical values for the hypothesized number of co-integrating equations at $5 \%$ level of significance, the test results indicate that there exist four co-integrating vectors in Table 5. This goes to validate the claim that there exists long-run equilibrium relationship between the growth in gross fixed capital formation and changes in the components of premium collected on different non-life insurance policies in Nigeria.

Table 6. Pairwise Granger causality test results

\begin{tabular}{llll}
\hline Null Hypothesis: & Obs & F-Statistic & Probability \\
\hline PF does not Granger Cause GFCF & 29 & 0.22831 & 0.87567 \\
\hline GFCF does not Granger Cause PF & & 0.4114 & 0.74642 \\
\hline PA does not Granger Cause GFCF & 29 & 0.97749 & 0.42127 \\
\hline GFCF does not Granger Cause PA & & 0.27961 & 0.83951 \\
\hline PMV does not Granger Cause GFCF & 29 & 0.49448 & 0.68981 \\
\hline GFCF does not Granger Cause PMV & & 0.53014 & 0.6663 \\
\hline PEL does not Granger Cause GFCF & 29 & 0.18283 & 0.90692 \\
\hline GFCF does not Granger Cause PEL & & 1.76256 & 0.18371 \\
\hline PMA does not Granger Cause GFCF & 29 & 0.23574 & 0.87048 \\
\hline GFCF does not Granger Cause PMA & & 0.04896 & 0.98528 \\
\hline
\end{tabular}

Source: Author's computation

From the probability value of the F-statistic in the pairwise granger causality tests conducted with a maximum lag of 3 , none of the independent variables appear to granger cause changes in the growth rate of gross fixed capital formation. That is, causality does not flow from the premium collected on the various types of non-life insurance policies to GFCF and vice versa. There is therefore no causal relationship between the dependent and independent variables in the model at 5\% significance level (See Table 6).

Table 7. Impulse response to one S.D innovations

\begin{tabular}{lllllll}
\hline \multicolumn{2}{l}{ Response of GFCF: } & \multicolumn{5}{l}{$l$} \\
\hline Period & GFCF & PF & PA & PMV & PEL & PMA \\
\hline 1 & 20.46639 & 0 & 0 & 0 & 0 & 0 \\
\hline 2 & -1.512188 & $3.47 \mathrm{E}-16$ & $1.12 \mathrm{E}-14$ & $3.99 \mathrm{E}-15$ & $-5.82 \mathrm{E}-15$ & $-2.56 \mathrm{E}-16$ \\
\hline 3 & -7.726233 & $2.65 \mathrm{E}-16$ & $1.09 \mathrm{E}-14$ & $6.62 \mathrm{E}-15$ & $-1.43 \mathrm{E}-15$ & $2.66 \mathrm{E}-16$ \\
\hline 4 & 1.149983 & $-1.52 \mathrm{E}-16$ & $-5.10 \mathrm{E}-15$ & $-2.02 \mathrm{E}-15$ & $2.33 \mathrm{E}-15$ & $7.83 \mathrm{E}-17$ \\
\hline 5 & 2.873928 & $-9.03 \mathrm{E}-17$ & $-3.80 \mathrm{E}-15$ & $-2.39 \mathrm{E}-15$ & $3.74 \mathrm{E}-16$ & $-1.08 \mathrm{E}-16$ \\
\hline 6 & -0.65275 & $6.50 \mathrm{E}-17$ & $2.23 \mathrm{E}-15$ & $9.49 \mathrm{E}-16$ & $-9.21 \mathrm{E}-16$ & $-2.20 \mathrm{E}-17$ \\
\hline 7 & -1.052391 & $2.98 \mathrm{E}-17$ & $1.29 \mathrm{E}-15$ & $8.44 \mathrm{E}-16$ & $-7.52 \mathrm{E}-17$ & $4.28 \mathrm{E}-17$ \\
\hline 8 & 0.327739 & $-2.71 \mathrm{E}-17$ & $-9.51 \mathrm{E}-16$ & $-4.26 \mathrm{E}-16$ & $3.58 \mathrm{E}-16$ & $5.28 \mathrm{E}-18$ \\
\hline 9 & 0.378816 & $-9.41 \mathrm{E}-18$ & $-4.24 \mathrm{E}-16$ & $-2.92 \mathrm{E}-16$ & $2.34 \mathrm{E}-18$ & $-1.68 \mathrm{E}-17$ \\
\hline 10 & -0.153503 & $1.11 \mathrm{E}-17$ & $3.96 \mathrm{E}-16$ & $1.85 \mathrm{E}-16$ & $-1.37 \mathrm{E}-16$ & $-7.81 \mathrm{E}-19$ \\
\hline
\end{tabular}

Source: Author's computation 
The impulse response of GFCF to own shock in the first year is $20.46 \%$ while GFCF response to shocks emanating from other variables in year one are all zero, showing that own shock is the dominant source of variation to growth in the level of gross fixed capital formation.

However, the responses of GFCF to innovations coming from the explanatory variables are not consistent in pattern but fluctuate over the forecast period of ten years into the future with a mix of increases and decreases in absolute values and high volatility in the coefficients.

Table 8. Variance decomposition test result

\begin{tabular}{llllllll}
\hline \multicolumn{7}{l}{ Variance Decomposition of GFCF: } \\
\hline \multicolumn{2}{l}{ Period S.E. } & GFCF & PF & PA & PMV & PEL & PMA \\
\hline 1 & 29.77050 & 100.0000 & 0.000000 & 0.000000 & 0.000000 & 0.000000 & 0.000000 \\
\hline 2 & 31.53575 & 89.12234 & 3.921803 & 3.935769 & 1.939448 & 0.780538 & 0.300105 \\
\hline 3 & 35.28889 & 77.51887 & 3.146038 & 6.865201 & 11.40099 & 0.817163 & 0.251742 \\
\hline 4 & 35.47080 & 77.08993 & 3.261327 & 6.798178 & 11.70720 & 0.809222 & 0.334142 \\
\hline 5 & 36.28192 & 74.00681 & 5.781700 & 6.592454 & 11.28790 & 1.696403 & 0.634734 \\
\hline 6 & 36.79240 & 71.96912 & 6.948571 & 6.520568 & 11.44228 & 2.431116 & 0.688341 \\
\hline 7 & 36.99137 & 71.25774 & 7.086764 & 6.681806 & 11.84140 & 2.421183 & 0.711102 \\
\hline 8 & 37.07815 & 70.95000 & 7.053698 & 6.754410 & 12.01454 & 2.513870 & 0.713480 \\
\hline 9 & 37.25123 & 70.36605 & 7.483158 & 6.762643 & 11.90551 & 2.713760 & 0.768879 \\
\hline 10 & 37.35186 & 69.98814 & 7.601456 & 6.790098 & 11.99504 & 2.854946 & 0.770320 \\
\hline
\end{tabular}

Source: Author's computation

In Table 8, the VDC analysis show that own shocks represent the dominant source of variation in the forecast errors of the variables in the model. For example, in the variance decomposition of GFCF, own shocks account for $100 \%$ in the first year and decreases steadily to $69.988 \%$ in the tenth year. Furthermore, the variances explained in GFCF by the explanatory variables in the second year for example are as follows: PF explained about 3.92\%; PA about 3.94\% while PMV explained about $1.94 \%$. This shows that GFCF is the most sensitive variable to itself among the specified variables.

From the results, though the innovation coming from GFCF to self represent the dominant source of variation in GFCF, the variation decreases as we move into the future. We notice that the variance decomposition of GFCF to shocks emanating from PF, PA, PMV, PEL and PMA appears to have been decreasing during the period (year 1 to year 3) but there after starts to rise from $3.26 \%, 6.8 \%, 11.7 \%, 0.8 \%$ and $0.33 \%$ in the $4^{\text {th }}$ year to $7.6 \%, 6.81 \%$, $11.99 \%, 2.9 \%$ and $0.77 \%$ in the $10^{\text {th }}$ year respectively. These confirm the significant impact of the components of insurance premium on Gross Fixed Capital Formation.

\section{Concluding Remarks}

This paper set out to investigate the effect of insurance fund mobilization on the growth of gross fixed capital formation in Nigeria. In an attempt to accomplish this, the study also sought to unveil the gross fixed capital formation response to innovations emanating from insurance premium/savings mobilization. The short run analysis shows that there exists positive and insignificant relationship between premium from fire, accidents, motor vehicle and employee liabilities insurance policies and Gross Fixed Capital Formation. This suggests that premium from nonlife insurance policies seems to positively correlate with the growth rate of Gross Fixed Capital Formation but the magnitude of its effect is so insignificant due possibly to insufficient fund mobilization by the insurance sector occasioned by low level of insurance penetration in the economy. The relationship between premium from marine insurance policies and GFCF is both negative and insignificant.

In the long run, the effects of insurance fund mobilization on the growth of gross fixed capital formation are positive and significant, indicating that there is a long run equilibrium relationship between gross fixed capital formation and fund mobilization activities by insurance companies in Nigeria at $5 \%$ level of significance. This supports the findings of Boon (2005) which show that total insurance funds influence capital formation in the long run. The pair wise granger causality test results reveal that there is no lead or follow relationship between the correlates.

The variance decomposition analysis shows that a large proportion of the forecast error of gross fixed capital formation could be attributed to own shocks emanating from gross fixed capital formation. However, the identified behavioral pattern of gross fixed capital formation in response to innovations provided by insurance fund mobilization is largely positive and expansionary thus capable of stimulating growth in capital formation into the 
future. This implies that if the managers of the Nigerian economy focus on formulating and implementing appropriate policies that will increase insurance penetration improve insurance fund mobilization and enlarge the insurance market, these will have positive expansionary effects on capital formation in Nigeria. This could be facilitated through the use of modern information technology to boost insurance patronage in Nigeria.

\section{References}

Agenor, P.R., \& Montiel, P.J. (1996). Development Macroeconomics. Princeton University Press.

Akaike, H. (1969). Fitting Autoregressive Models for Regression. Annals of the Institute of Statistical Mathematics, 21, 243-247. http://dx.doi.org/10.1007/BF02532251

Anderson, D.R., Sweeney, D.J., \& Williams, T.A. (1993). Statistics for Business and Economics (5 ${ }^{\text {th }}$ ed.). New York: West Publishing Company.

Avram, K. (2010). Insurance and Growth: A Cross Country Examination. Australian Centre for Financial Studies. Finsia Banking and Finance Conference 2010.

Avram, K.Y. Nguyen, \& M. Skully. (2010). Insurance and Economic Growth: A Cross Country Examination. Monash University, Dept of Accounting and Finance, Working Paper.

Boon, T.K. (2005). Do Commercial Banks, Stock Market and Insurance Market Promote Economic Growth? An Analysis of the Singapore Economy. Nanyang Technological University, School of Humanities and Social Studies, Working Paper.

Catalan, M.G., Impavido, G., \& Musalem, A.R. (2000). Contractual Savings or Stocks Market Development: Which Leads? Journal of Applied Social Science Studies, 120(3), 445-87. also available at the World Bank Policy Research Working Paper no 2421.

Cookey, A.E. (1997). Commercial Banks' Loan Portfolio and Monetary Policy in Nigeria: An Empirical Analysis. The Journal of Business, Industrial and Economic Research, 1(2), 226-237.

Curak, M., Loncar, S., \& Poposki, K. (2009). Insurance Sector Development and Economic Growth in Transition Countries. International Research Journal of Finance and Economics, 34(1), 29-41.

Dickey, D.A., \& Fuller, W.A. (1981). Distribution of the Estimators for Autoregressive Time Series with a Unit Root. Journal of the American Statistical Association, 74, 427-431.

Dooley, D. (1984). Social Research Methods. New Jersey, Prentice-Hall Inc., pp. 225-227.

Engle, R.F., \& Granger, C.W. (1987). Co-integration and Error Correction: Representation, Estimation and Testing. Econometrica, 55, 251-276. http://dx.doi.org/10.2307/1913236

Ezirim, C.B. (1999). Intermediation Functions of Superstructure and Economic Growth: Evidence from Nigeria. Unpublished Ph.D. Dissertation, University of Port Harcourt.

Ezirim, C.B. (2004). Risk and Insurance in Nigeria: Principles and Applications. Port Harcourt, Markowitz Center for Research and Development.

Fraser, D.R.S., \& Ross, P.S. (1973). Short-Run Bank Portfolio Behavior: An Examination of Selected Liquid Assets. Journal of Finance, 9, 531-537. http://dx.doi.org/10.1111/j.1540-6261.1973.tb01801.x

Gardner, B., \& Gardner, H. (1998). More than Cost Shifting: Moral Hazard Lowers Productivity. Journal of Risk and Insurance, 67(1), 73-90

Granger, C.W.J. (1969). Investigating Causal Relations by Economic Models and Cross-Spectral Methods. Econometrica, 35, 25-27.

Granger, C.W.J. (1991). Long-Run Economic Relationships: Readings in Co-integration, Chapter 13. Oxford University Press, New York.

Gujarati, D.N., \& Porter, D.C. (2009). Basic Econometrics (5 ${ }^{\text {th }}$ ed.). New York, McGraw-Hill/Irwin.

Haiss, P., \& Sumegi, K. (2008). The Relationship between Insurance and Economic Growth in Europe: A Theoretical and Empirical Analysis. Empirica, 35(4), 405-431. http://dx.doi.org/10.1007/s10663-008-9075-2

King, R.G., \& Levine, R. (1993). Finance and Growth: Schumpeter Might be Right. Quarterly J. Econ., 108(3), 717-737. http://dx.doi.org/10.2307/2118406 
Kong, J., \& Singh, M. (2005). Insurance Companies in Emerging Markets. IMF Working Paper 05/88, May. http://dx.doi.org/10.5089/9781451861075.001

Kugler, M., \& Ofoghi, R. (2005). Does Insurance Promote Economic Growth?: Evidence from the U.K.. University of Southampton, Division of Economics, Working Paper.

Lambo, E. (1986). Commercial Bank Portfolio Management. In Ademola Oyejide \& Afolabi Soyode (Eds.), Commercial Banking in Nigeria: Evolution, Regulation and Performance. Ibadan: Unibadan Publishing Consultants.

Laws of the Federal Republic of Nigeria, The Insurance Act of Nigeria 2003.

Laws of the Federal Republic of Nigeria, The Pension Reform Act of Nigeria 2004.

Levine, R. (1999). Law, Finance, and Economic Growth. Journal of Financial Intermediation, 8(12), 8-35. http://dx.doi.org/10.1006/jfin.1998.0255

Levine, Ross. (2004). Finance and Growth: Theory and Evidence. Forthcoming Handbook of Economic Growth.

Mojekwu, J.N., Agwuegbo, S.O.N., \& Olowokudejo, F.F. (2011). The Impact of Insurance Contributions on Economic Growth. Journal of Economics and International Finance, 3(7), 444-451.

Nyong, M. (1996, December). Banking Supervision and the Safety-Soundness of the Banking System: An Early Warning Model Applied To Nigeria Data. CBN Economic and Financial Review, 32(4).

Oluyemi, S.A. (1995). Recent Developments in the Nigerian Banking System and Insured Banks Asset Portfolio Behaviour: An Empirical Study. NDIC Quarterly, 5(4),

Osipitan, T. (2009). Legal Regulation of Insurance Business in Nigeria: Problems and Prospects. Chartered Insurance Inst. Nig. J., 11(1), 69-82.

Outreville, J. F. (1990). The Economic Significance of Insurance Markets in Developing Countries. The Journal of Risk and Insurance, 57(3), 487-498. http://dx.doi.org/10.2307/252844

Park, H., S.F. Borde, \& Y. Choi. (2002). Determinants of Insurance Pervasiveness: A Cross-National Analysis. International Business Review, 11(1), 79-96. http://dx.doi.org/10.1016/S0969-5931(01)00048-8

Reed, E.W., R.V. Cotter, E.K. Gill, \& R.K. Smith. (1980). Commercial Banking (2 ${ }^{\text {nd }}$ ed.). Prentice Hall, New Jersey.

Skipper, H. Jr. (1997). Foreign Insurers in Emerging Markets: Issues and Concerns. Center for Risk Management and Insurance, Occasional Paper 97-2.

Ward, D., \& R. Zurbruegg. (2000). Does Insurance Promote Economic Growth? Evidence from OECD Countries. The Journal of Risk and Insurance, 67(4), 489-506. http://dx.doi.org/10.2307/253847

Webb, I.P., M.F. Grace, \& H. Skipper. (2002). The Effect of Banking and Insurance on the Growth of Capital and Output, Georgia State University, Center for Risk Management and Insurance, Working Paper 02-1. 